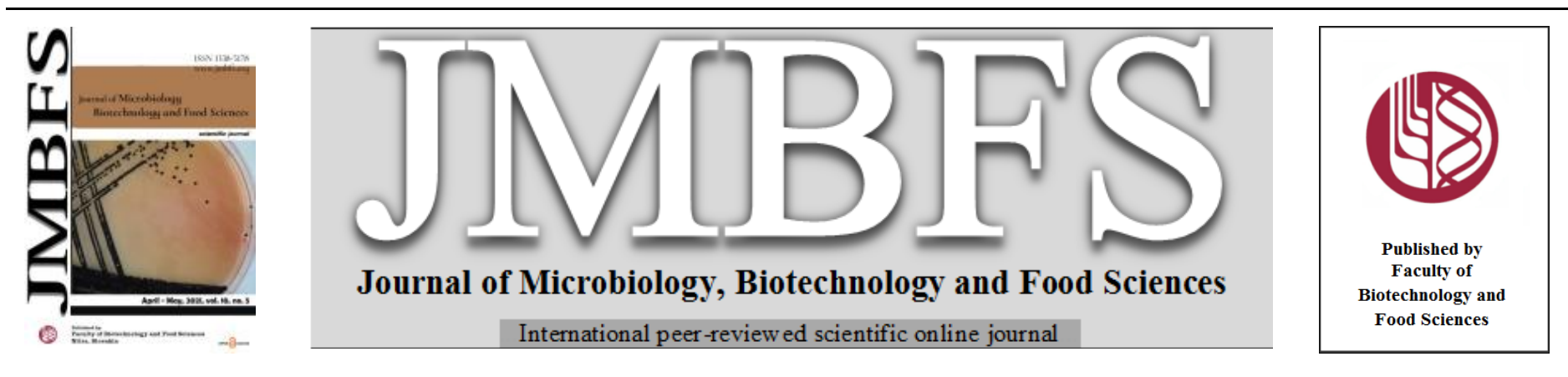

\title{
SUPPRESSION OF AFLATOXINS PRODUCTION IN ARTIFICIALLY INFESTED MAIZE GRAINS WITH ASPERGILLUS FLAVUS DURING STORAGE CONDITIONS
}

\author{
Abdel-Kader, M.M. ${ }^{1}$,El-Mougy, N.S. ${ }^{1}$, Soliman, K.M. ${ }^{2}$ and Abd-Elfatah, S.I. ${ }^{2}$ \\ Address(es): \\ ${ }^{1}$ National Research Centre, Plant Pathology Dept., Dokki, Giza, 12622, Egypt. \\ ${ }^{2}$ National Research Centre, Food Toxicology \&Contaminant Dept., Dokki, Giza, 12622, Egypt. \\ *Corresponding author: simaged@yahoo.com
}

https://doi.org/10.15414/jmbfs.2243

\section{ARTICLE INFO}

Received 27. 10. 2019

Revised 15. 11. 2020

Accepted 23. 11.2020

Published 1. 4. 2021

Regular article

OPEN $\partial$ ACCESS

\begin{abstract}
Maize is the one of important crops in Egypt. Aflatoxins (AFs) are the foremost cancer present compounds by Aspergillus flavus (A. flavus) and cause health risks to human and animals. This study aimed to suppression of aflatoxins production by A. flavus by using different concentrations of natural substances (carnation oil, lemongrass oil, propolis and beewax) and chemical substances (salicylic acid and potassium sorbate) on maize grains. The strains of A. flavus were isolated from local maize grains on Potato Dextrose Agar (PDA) and detect its ability of aflatoxins production on coconut agar media. Samples (100g) of sterilized maize grains were treated individually with different concentration of carnation oil, lemongrass oil, salicylic acid and potassium sorbate $(0.25,0.5,1.0,2.0,4.0$ and $6.0 \%$ ) and at concentration $1 \%$ and $4 \%$ for propolis and beeswax each, then inoculated with A. flavus and stored for 30 days at $28 \pm 2^{\circ} \mathrm{C}$. AFs reduction was determined by using High Performance liquid Chromatography (HPLC). All the tested substances had active effect in inhibition of AFs production by A. flavus in stored maize grains. The production of Aflatoxin $\mathrm{B}_{1}$ and $\mathrm{B}_{2}\left(\mathrm{AFB}_{1}\right.$ and $\mathrm{AFB}_{2}$ ) was decreased to about $93 \%$ and $99 \%$ at concentration of $0.25 \%$ carnation oil. Lemongrass oil almost completely inhibited $\mathrm{AFB}_{1}$ and $\mathrm{AFB}_{2}$ production (99.12\% - 99.98\% and $99.98 \%-99.99 \%$, respectively) at concentration of $2 \%-6 \%$. Potassium sorbate and salicylic acid $(0.25 \%-6 \%)$ that were significantly effective controlling aflatoxins production on maize grains compared with control. While, the propolis and beewax found to be the most active to protect maize grains against fungi. Natural substances, carnation oil, lemongrass oil, beewax and propolis had higher active effect at low concentration on aflatoxin production more than salicylic acid and more safe for human used.
\end{abstract}

Keywords: Aflatoxins, Aspergillus flavus, natural substance, chemical substance, maize

\section{INTRODUCTION}

Maize (Zea mays) is that the third field crop within the world, also considered as one of important crops in Egypt. It's planted on 378,000 Fadden of land (FAO, 2013). Within the storage, amount several pests and parasites attack maize. However, fungi also are vital and thought of because the second explanation for grain losses (Ominski et al., 1994 and Kumari et al., 2019).

Aspergillus species could be a quite common fungus within the setting, and may be a problem in hold on grains. Fungus genus, A. parasiticus and A. flavus synthesize aflatoxins once they grow on a variety of vulnerable food and feed crops. These fungi are reported together of the extreme contaminants of varied plants and plant material like maize, peanuts, rice, cotton seeds and spices, in addition to exploit product (El-Nagerabi et al., 2012). Aflatoxins are among the foremost cancer present compounds acknowledged (or identified) and that they cause vital health risks to humans and animals (Elshafie $\boldsymbol{e t}$ al., 2011 and Qureshi et al., 2015).

Over the past few years, there are varieties of approaches that may be taken to attenuate aflatoxins contamination in grains and these involve prevention of fungal growth and therefore aflatoxins formation to reduce or eliminate aflatoxins from contaminated grains. It's a well-established undeniable fact that, some plant based mostly essential oils contain compounds that are able to inhibit plant growth, there's appreciable interest in these essential oils from aromatic plants with antimicrobial properties to manage pathogens and toxin-producing molds (Soliman and Badeaa, 2002 and Tepe $\boldsymbol{e t}$ al., 2005). Though the bulk of the essential oils are classified as usually Generally Recognized As Safe (GRAS), their use in foods as preservatives is usually restricted because of flavor issues (Lambert et $\boldsymbol{a l . , 2 0 0 1 ) . ~ A t ~ t h e ~ p r e s e n t ~ m a n y ~ p r o d u c t ~ a r e ~ u s e d ~ a s ~ a n t i f u n g a l ~}$ agents together with common preservatives as essential oils like carnation and lemongrass (Smith-palmer et al., 2001), organic acid (salicylic acid) (Rajesh and Mubasshirin, 2018), organic salt (potassium salt) (Merck, 2015) and natural products as beeswax and propolis (Buchta et al., 2011). Propolis is that the resinous substance collected honey bees from numerous plant sources. The antifungal activity of propolis has been evaluated by Quiroga et al., 2006; Aly and Elewa, 2007; Ghasem et al., 2007 and Yang et al., 2010. The chemical composition of propolis is extremely complex, containing over 150 elements like flavonoids, phenolic resin acids and their esters, alcohols, ketones, amino acids, and inorganic compounds (Hegazi et al., 2000; Banskota et al., 2001; Marcucci et al., 2001 and Bankova, 2005a). The honeybee's wax has a very wide spectrum of useful applications, cosmetics, food process (food packaging, process and preservation - natural additive) and medication (coating pills, antibiotic properties) (Krell, 1996).

Therefore, in the present investigation, suppression of aflatoxin production of $A$ flavus by several substances either natural as carnation oil and lemongrass oil, propolis and beewax or chemical as salicylic acid and potassium sorbate were evaluated for their efficacy as preservative against aflatoxigenic fungi in maize grains.

\section{MATERIALS AND METHODS}

\section{Isolation and identification of $A$. flavus}

Maize grains were collected from local markets in Egypt. The surface sterilized maize grains were placed on Potato Dextrose Agar (PDA) medium and incubation at $28 \pm 2{ }^{\circ} \mathrm{C}$ for 7 days. At the end of the incubation period, Aspegillia isolates of fungal were identified based on light macroscopic and microscopical characteristics. Aspegillia isolates of fungal colonies were transferred onto fresh PDA plates to study their morphological characteristics. The isolates were identified using the taxonomic key prepared by using fungal keys and manuals (Klich, 2002 and Samson et al. 2004). 
Mycotoxicological analysis of $A$. flavus isolates

The ability of A. flavus isolates for production of AFs was examined using coconut agar media (CAM) (100 g of sliced coconut was homogenized for $5 \mathrm{~min}$. with $300 \mathrm{ml}$ of hot water. Then filtrate and adjust $\mathrm{pH}$ to 7.0 using $2 \mathrm{~N} \mathrm{NaOH}$ and adding 20g/L agar then autoclave, Davis et al., 1987). Plug from A. flavus (39 isolates) was placed on the center of CAM plates and incubated for 7 days. After the incubation period, plates were examined under (UV) lamp in a dark room for fluorescence to detect the presence of aflatoxin production. If the mould fluoresced under UV light was considered to be aflatoxin positive and confirmed as an aflatoxigenic form of $A$. flavus.

\section{Screening and detecting of aflatoxins produced by different isolates of $A$ flavus}

To confirm the correlation between fluorescence and aflatoxin production, five of toxigenic strains of A. flavus (NOs.1, 2, 5, 7 and 8) were used in this test. The colonies were grown on Yeast Extract Sucrose (YES; $2 \%$ yeast extract and 20\% sucrose) (Abdollahi and Buchanan, 1981). Spore suspensions of the isolates were prepared and adjusted to approximately $10^{6}$ spores $/ \mathrm{ml}$ by using a hemocytometer. One $\mathrm{ml}$ spore suspension was inoculated into $50 \mathrm{~mL}$ of sterile YES and incubated at $25{ }^{\circ} \mathrm{C}$ for 14 days. The entire culture was filtrated by filter paper No.3, the filtrate was transferred to separating funnel and extracted with chloroform (50 mlx3) (Fente et al., 2001). The chloroform extracts were evaporated to dryness and redissolved in $1 \mathrm{ml}$ chloroform (Kumar et al., 2010). Aflatoxins were qualitatively detected by thin layer chromatography (TLC, $20 \times 20 \mathrm{~cm}$ ). $10 \mu \mathrm{l}$ of the extracts and standard aflatoxins (sigma CO) were spotted on the TLC. The spotted plates were developed in developing system (toluene: ethyl acetate: formic acid, 6:3:1, v/v/v), and examined under long wave UV light (365 $\mathrm{nm}$ ) (Abarca et al., 1994). Compare sample aliquot to aflatoxins standard for the presence of blue $\left(\mathrm{AFB}_{1}\right.$ and $\left.\mathrm{AFB}_{2}\right)$ fluorescent spots and Rf similar to those in standards.

Two $\mathrm{AFB}_{1}$ and $\mathrm{B}_{2}$ producing $A$. flavus isolates (5 and 7) were inoculated with sterilized maize grains and incubated for 30 days. The extraction, clean up and determination of aflatoxins were done according to AOAC (2016).

\section{Preparation of test materials}

\section{Natural substance}

Essential oils (carnation, lemongrass): they were purchased from Cairo Company for oils and aromatic extractions CID, Egypt. Essential oils were stored in dark glass bottles at $4^{\circ} \mathrm{C}$ until use. Emulsified stocks at high concentration of tested materials were prepared by dissolving in sterilized distilled water $\left(\mathrm{dH}_{2} \mathrm{O}\right)$ A few drops of the emulsifier Tween 80 (Sigma Co.) were added the prepared emulsifier volumes (Awadall et al, 2008).

Natural products (propolis and beewax): purchased from local market Propolis sample was kept at room temperature in dark. Crude propolis was grounded into powder and macerated in acetic acid $(4 \mathrm{~g}$ propolis $+96 \mathrm{ml}$ acetic acid) and lactic acid (4g propolis $+96 \mathrm{ml}$ lactic acid). The extract of propolis was filtered through Whatman No. 1 filter paper to obtain a stock solution (4\%). Meanwhile beeswax was melted at $65^{\circ} \mathrm{C}$ in hot water, prior to use, at the rate of 4g beeswax: $96 \mathrm{ml}$ water (Badawy, 2016 and Abdel-Kader, et al., 2019).

\section{Chemical substance}

Organic acid (salicylic acid), Organic salt (potassium sorbate) were purched from (Sigma- Aldrich).

Prior maize grains treating, dilutions of working solutions were prepared at concentration $0.25,0.5,1.0,2.0,4.0$ and $6.0 \%$ for carnation oil, lemongrass oil, salicylic acid and potassium sorbate and $1 \%$ and $4 \%$ for propolis and beeswax.

\section{Evaluation of aflatoxins production in treated, stored maize grains}

One hundred grams of maize grains was placed in flasks $(500 \mathrm{ml})$ with $10 \mathrm{ml}$ of $\mathrm{dH}_{2} \mathrm{O}$ and sterilized for $20 \mathrm{~min}$ in an autoclave. Each sterilized flask of maize grains were treated individually with the tested materials at the proposed concentrations and shaken for few min. The day after, all the treated maize grain were inoculated with $2 \mathrm{~mL}$ A. flavus (isolate No. 5 that recorded the highest aflatoxin production) spore suspension $\left(10^{6}\right.$ spore $\left./ \mathrm{ml}\right)$, shaken well. The treated and un-treated inoculated maize grains were stored for 30 days at $28 \pm 2^{\circ} \mathrm{C}$. Afte incubation period, the moldy maize grains were autoclaved at $100{ }^{\circ} \mathrm{C}$ for $30 \mathrm{~min}$ and used for the extraction of aflatoxins according to CB method (AOAC, 2016).

\section{Determination of aflatoxins in maize grains}

The determination of Aflatoxins (AFs) was performed using High Performance liquid Chromatography (HPLC), according to (AOAC, 2016). The HPLC system used for AFs determination was ultimate 3000 Thermo Fisher system (Germany) equipped with auto sampler, pump, fluorescence detector and a C18 column chromatography Phenomenex $(250 \times 4.6 \mathrm{~mm}, 5 \mu \mathrm{m})$. The mobile phase, water: methanol: acetonitrile (60:30:10, v/v/v), was isocratically flowed at $1.2 \mathrm{ml} / \mathrm{min}$ AFs were measured at $360 \mathrm{~nm}$ excitation and $440 \mathrm{~nm}$ emission wave length.

\section{Statistical analysis}

Results were subjected to one-way analysis of variance (ANOVA) of the general liner model (GLM) using SAS (1999) statistical package. The results were the average of three replicates $(\mathrm{p} \leq 0.05)$.

\section{RESULTS}

Screening and detecting of aflatoxins produced by different isolates of $A$ flavus

Based on the cultural and physiological characteristics, thirty-nine isolates were referred to as $A$. flavus from maize grain samples using a taxonomical key and species represented by (Klich, 2002 and Samson et al., 2004). The detection of aflatoxigenic and non aflatoxigenic A. flavus isolates by using ultraviolet light (UV) revealed that five $(12.82 \%)$ of isolates (NOs. 1,2,5,7 and 8) were aflatoxigenic (positive) and $34(87.18 \%)$ of isolates were non-aflatoxigenic (negative). The detection by UV at $365 \mathrm{~nm}$ recognized aflatoxigenic by turn out blue fluorescent colonies within the center of glass petri dish of CAM.

Thin layer chromatography analysis for aflatoxins production by Aflatoxigenic isolates on (YES) medium showed blue fluorescing spots (Fig 1) under long wave UV (365 nm) parallel to $\mathrm{AFB}_{1}$ and $\mathrm{AFB}_{2}$ standards. The results of TLC showed that, five tested of $A$. flavus isolates (NOs. 1, 2, 5, 7 and 8) were able to produce one or more types of aflatoxin(s). In this respect, isolates NOs.1, 2 and 8 produced $\mathrm{AFB}_{1}$ only, whereas, isolates NOs. 5 and 7 produced $\mathrm{AFB}_{1}$ and $\mathrm{B}_{2}(\mathbf{F i g}$ 1). From the quantitative method of HPLC the concentration of $\mathrm{AFB}_{1}$ and $\mathrm{AFB}_{2}$ produced by isolates (NOs 5 and 7) were calculated. It was found that the concentration of $\mathrm{AFB}_{1}$ was calculated as 1060 and $608 \mu \mathrm{g} / \mathrm{kg}$ maize grains for strain 5 and 7, respectively. Meanwhile, the concentration of $\mathrm{AFB}_{2}$ was 460 and $700 \mu \mathrm{g} / \mathrm{kg}$ maize grains for strain 5 and 7 , respectively. So, the total production of $\mathrm{AFB}_{1}$ and $\mathrm{B}_{2}$ calculated as 1520 and $1308 \mu \mathrm{g} / \mathrm{kg}$ maize grains for the two isolates 5 and 7, respectively, on the basis of capability to produce.

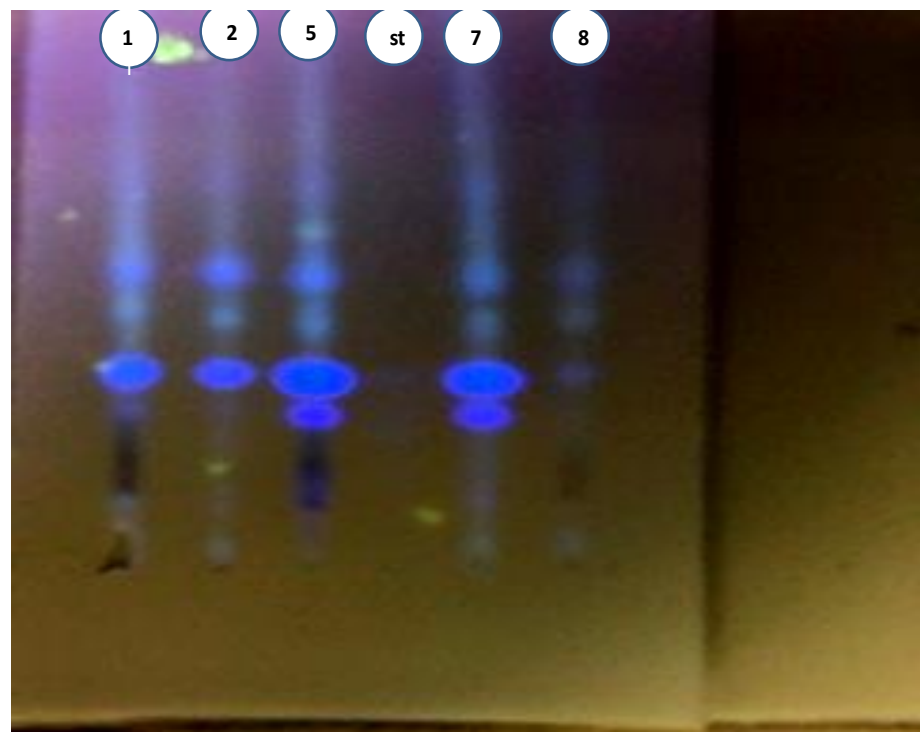

Figure 1 Thin layer chromatography screening for $\mathrm{AFB}_{1}$ and $\mathrm{AFB}_{2}$ production by A. flavus isolates (No.1, 2, 5, 7 and 8).St: standard of AFs

\section{Determination of aflatoxins production in treated maize grains}

Table 1 represented the effect of essential oils (carnation, lemongrass) on AFB and $\mathrm{AFB}_{2}$ production by $A$. flavus in stored maize grains. The highest decrease in $\mathrm{AFB}_{1}$ production was observed in carnation oil at concentration $2-4 \%(0.21$ $0.01 \mu \mathrm{g} / \mathrm{kg}$ ) while; $\mathrm{AFB}_{2}$ was highly decreased at $1-4 \%$ of carnation oil However, carnation oil suppressed the production of $\mathrm{AFB}_{2}$ to more than $99 \%$ from the concentration of $0.25 \%$. The complete reduction of $\mathrm{AFB}_{1}$ and $\mathrm{AFB}_{2}$ production was recorded at $6 \%$ (Figs 2 and 3 ).

Figs 2 and 3 illustrated the reduction percentage of $A_{F B}$ and $B_{2}$ after treated with carnation oil and lemongrass oil. $\mathrm{AFB}_{1}$ production rate was reduced about $75.34 \%, 90.88 \%$ and $97.06 \%$ following treatment with lemongrass oil at a concentration of $0.25 \%, 0.5 \%$ and $1 \%$, respectively. However, $\mathrm{AFB}_{1}$ and $\mathrm{AFB}_{2}$ production by $A$. flavus was approximately complete inhibited by treatment with $2 \%$ of lemongrass oil $(99.12 \%-99.98 \%)$, respectively and by $6 \%$ of lemongrass oil $(99.98 \%-99.99 \%)$, respectively (Figs 2 and 3). There was a significant 
difference in aflatoxins production of control compared with the carnation oil and lemongrass oil treated samples (Table 1).In the current study, carnation oil had the highest reduction effect on $\mathrm{AFB}_{1}$ and $\mathrm{B}_{2}$ production were recorded form concentration $(0.25 \%$ - $1 \%)$ compared with lemongrass oil.

Table 1 Effect of carnation oil and lemongrass oil on $\mathrm{AFB}_{1}$ and $\mathrm{AFB}_{2}$ production by A. flavus in stored maize grains

\begin{tabular}{llcc}
\hline Treatment & Con. $\%$ & \multicolumn{2}{c}{$\begin{array}{c}\text { Aflatoxins concentration }(\boldsymbol{\mu g} / \mathbf{k g}) \\
(\mathbf{m e a n} \pm \mathbf{S E})\end{array}$} \\
\hline Control & - & $\mathbf{B}_{\mathbf{1}}$ & $\mathbf{B}_{2}$ \\
\hline & 0.25 & $1060.0 \pm 6.928^{\mathrm{a}}$ & $460.0 \pm 7.506^{\mathrm{a}}$ \\
\hline & 0.50 & $6.0 \pm 1.155^{\mathrm{b}}$ & $1.7 \pm 0.116^{\mathrm{b}}$ \\
Carnation oil & 1.0 & $0.69 \pm 0.020^{\mathrm{d}}$ & $0.27 \pm 0.023^{\mathrm{b}}$ \\
& 2.0 & $0.21 \pm 0.023^{\mathrm{d}}$ & $0.0 \pm 0.0$ \\
& 4.0 & $0.01 \pm 0.001^{\mathrm{d}}$ & $0.02 \pm 0.002^{\mathrm{b}}$ \\
& 6.0 & $0.0 \pm 0.0$ & $0.0 \pm 0.0$ \\
\hline Lemongrass & 0.25 & $261.3 \pm 1.819^{\mathrm{b}}$ & $8.71 \pm 0.687^{\mathrm{b}}$ \\
oil & 0.50 & $96.7 \pm 0.693^{\mathrm{c}}$ & $3.68 \pm 0.116^{\mathrm{b}}$ \\
& 1.0 & $31.2 \pm 2.424^{\mathrm{d}}$ & $0.14 \pm 0.017^{\mathrm{b}}$ \\
& 2.0 & $9.3 \pm 0.058^{\mathrm{e}}$ & $0.07 \pm 0.002^{\mathrm{b}}$ \\
& 4.0 & $0.27 \pm 0.014^{\mathrm{f}}$ & $0.19 \pm 0.082^{\mathrm{b}}$ \\
\hline
\end{tabular}

* Con\%.: Concentration\%

Data are presented as the mean $\pm \mathrm{SE}$, different superscript letters within column are significantly different $(\mathrm{p}=0.051)$.

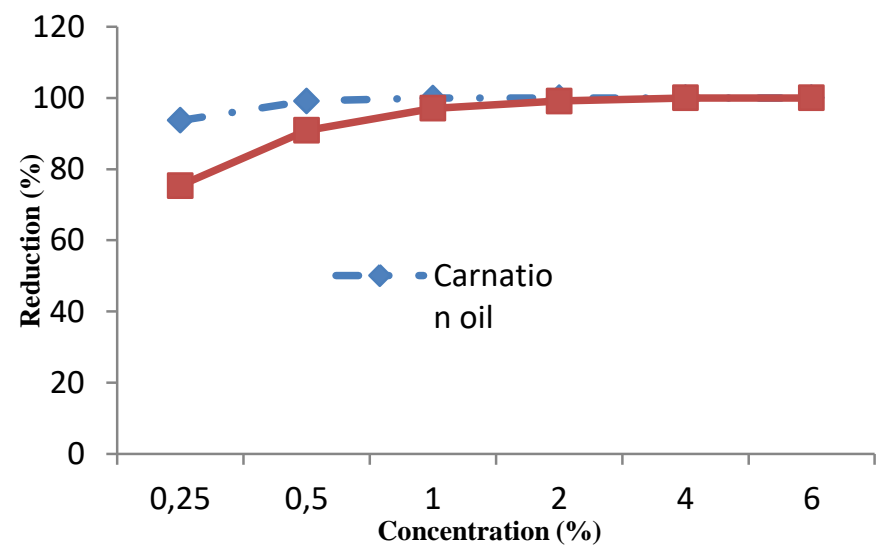

Figure 2 Reduction percentage of $\mathrm{AFB}_{1}$ production in stored maize grains after treatment with carnation oil and lemongrass oil

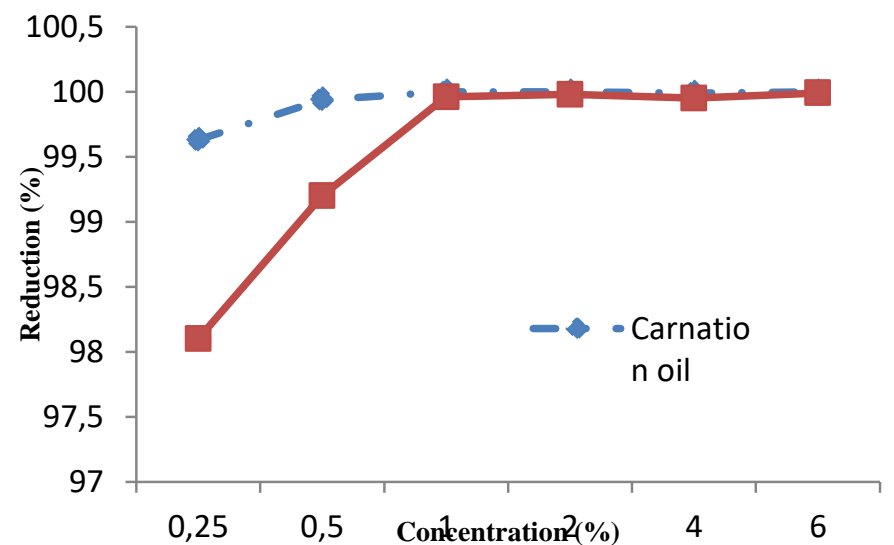

Figure 3 Reduction percentage of $\mathrm{AFB}_{2}$ production in stored maize grains after treatment with carnation oil and lemongrass oil

Data presented in Table (2) showed that potassium sorbate and salicylic acid had a highly effect on the reduction of $\mathrm{AFB}_{1}$ and $\mathrm{B}_{2}$ at all concentration. Both potassium sorbate and salicylic acid at different concentrations from $0.25 \%$ to $6 \%$ that were significantly effective in controlling aflatoxin production on maize grains caused by A. flavus compared with control. The highest decrease of AFB and $\mathrm{AFB}_{2}$ were observed in $4 \%$ of potassium sorbate $(99.97 \%$ and $99.98 \%)$ and salicylic acid $98.27 \%$ - 99.95\%). While, the completely reduction of AFs production observed at $6 \%$ of both.

Potassium sorbate was recorded a reduction percent $(99.83 \%-100 \%)$ for $\mathrm{AFB}_{1}$ and $(99.74 \%-100 \%)$ for $\mathrm{AFB}_{2}$ production. While, Salicylic acid, the minimum inhibition of $\mathrm{AFB}_{1}(83.28 \%)$ and $\mathrm{AFB}_{2}(91.86 \%)$ caused by salicylic acid in $0.25 \%$, whereas the maximum reduction of $\mathrm{AFB}_{1}$ and $\mathrm{AFB}_{2}$ were $(100 \%)$ that exhibited by $6 \%$ salicylic acid, these results shown in Figs 4 and 5. Nevertheless, the propolis and beeswax found to be the most active substance as preservative material on maize grains.

Table 2 Effect of potassium sorbate and salicylic acid on the production of $\mathrm{AFB}_{1}$ and $\mathrm{AFB}_{2}$ by A. flavus in stored maize grains

\begin{tabular}{llcc}
\hline \multirow{2}{*}{ Treatment } & Con. $\%$ & \multicolumn{2}{c}{$\begin{array}{c}\text { Aflatoxins concentration }(\boldsymbol{\mu g} / \mathbf{k g}) \\
\text { (mean } \pm \text { SE) }\end{array}$} \\
\cline { 2 - 4 } Control & - & \multicolumn{1}{c}{$\mathrm{B}_{1}$} & $\mathrm{~B}_{2}$ \\
\hline \multirow{4}{*}{$\begin{array}{l}\text { Potassium } \\
\text { sorbate }\end{array}$} & 0.25 & $1060.0 \pm 6.928^{\mathrm{a}}$ & $460.0 \pm 7.506^{\mathrm{a}}$ \\
\cline { 2 - 4 } & 0.50 & $0.99 \pm 0.069^{\mathrm{b}}$ & $0.28 \pm 0.017^{\mathrm{b}}$ \\
\cline { 2 - 4 } & 1.0 & $0.79 \pm 0.017^{\mathrm{b}}$ & $0.00 \pm 0.000$ \\
\hline & 2.0 & $0.41 \pm 0.017 \mathrm{~b}$ & $0.17 \pm 0.017^{\mathrm{b}}$ \\
\hline & 4.0 & $0.24 \pm 0.023^{\mathrm{b}}$ & $0.09 \pm 0.010^{\mathrm{b}}$ \\
\cline { 2 - 4 } & 6.0 & $0.00 \pm 0.000$ & $0.00 \pm 0.000$ \\
\hline \multirow{3}{*}{ Salicylic acid } & 0.25 & $177.22 \pm 3.47^{\mathrm{b}}$ & $37.44 \pm 1.755^{\mathrm{b}}$ \\
\cline { 2 - 4 } & 0.50 & $108.20 \pm 1.790^{\mathrm{c}}$ & $36.72 \pm 0.837^{\mathrm{b}}$ \\
\cline { 2 - 4 } & 1.0 & $49.66 \pm 2.373^{\mathrm{d}}$ & $31.20 \pm 1.270^{\mathrm{b}}$ \\
\cline { 2 - 4 } & 2.0 & $36.80 \pm 1.386^{\mathrm{e}}$ & $13.30 \pm 0.231^{\mathrm{c}}$ \\
\cline { 2 - 4 } & 4.0 & $18.32 \pm 0.751^{\mathrm{f}}$ & $0.19 \pm 0.017^{\mathrm{d}}$ \\
\cline { 2 - 4 } & 6.0 & $0.00 \pm 0.000$ & $0.00 \pm 0.000$ \\
\hline
\end{tabular}

Data are presented as the mean \pm SE, different superscript letters within column are significantly different $(\mathrm{p}=0.051)$.

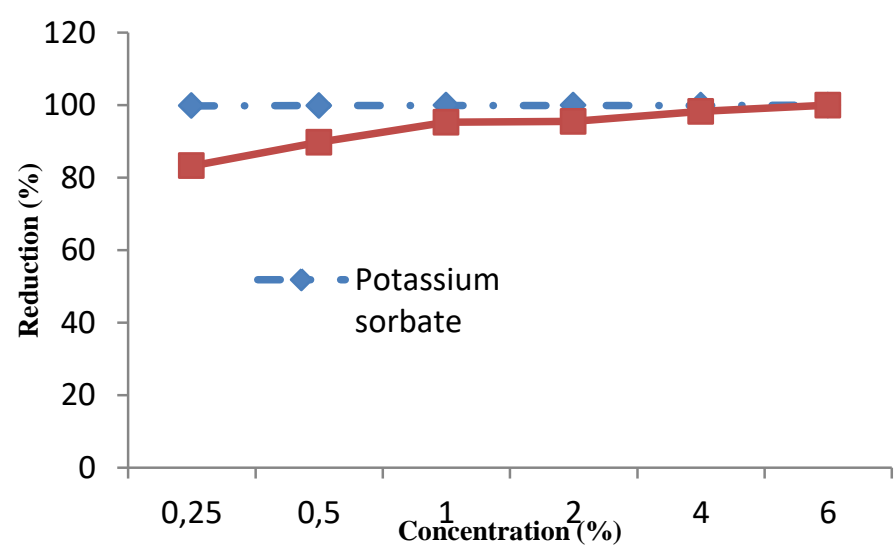

Figure 4 Reduction percentage of $\mathrm{AFB}_{1}$ production in stored maize grains after treatment with potassium sorbate and salicylic acid

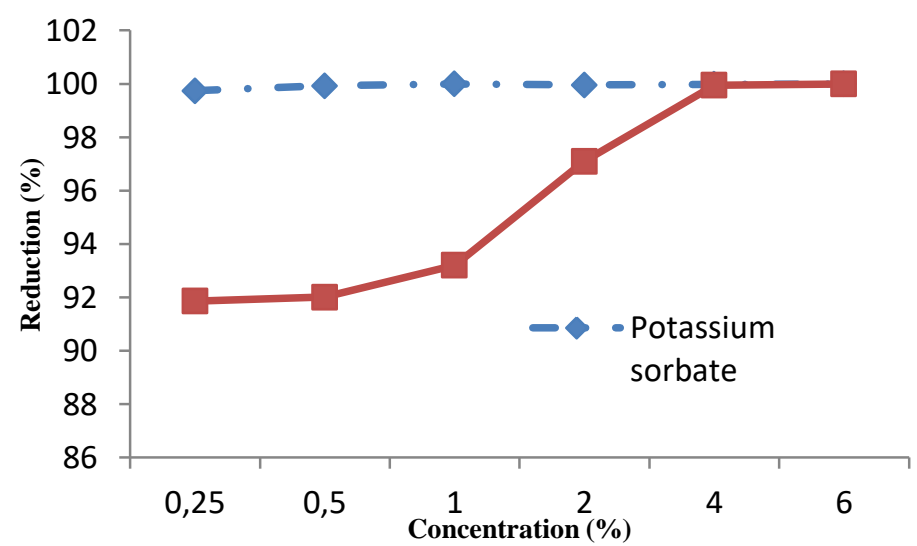

Figure 5 Reduction percentage of $\mathrm{AFB}_{2}$ production in stored maize grains after treatment with potassium sorbate and salicylic acid

\section{DISCUSSION}

In the present study, five strains of $A$. flavus isolated from maize grains were used to evaluate their ability to produce aflatoxin(s) in synthetic medium (YES).The most aflatoxigenic isolates of $A$. flavus was used to estimate the production of $\mathrm{AFB}_{1}$ and $\mathrm{AFB}_{2}$ in stored maize grains for 30 days treated with different concentrations of carnation oil, lemongrass oil, salicylic acid, potassium sorbate, beeswax and propolis. It is well known that aflatoxigenic fungi are frequently found in foodstuffs and animal feeds and are associated with a wide spectrum of 
stored agricultural commodities. However, not all Aspergillus species are able to produce aflatoxins

In this concern, regional variations in biological weapon contamination of crops is also thanks to atmospheric condition and to agricultural practices that increase condition of plants to invasion by A. flavus and ratio plays an important role within the development and unfold of plant life contaminations (Nawar, 2008 and Fountain et al., 2014) and pre-harvest conditions of temperature and humidity in the field and improper postharvest handling and storage.

Over the past few years, a lot of effort has been place into research on new antifungal agents to regulate the expansion of Aspergillus species in cereals supposed for human and animal consumption (Soliman and Badeaa, 2002; Sukatta et al., 2008 and Abdel-Rahman et al., 2019). One methodology of preventing mycotoxin contamination is to inhibit the expansion of mycotoxinproducing molds by totally different ways. The essential oils (carnation and lemongrass), salicylic acid and potassium sorbate lead to a decrease in aflatoxins $\left(\mathrm{B}_{1}\right.$ and $\mathrm{B}_{2}$ ) produced by $A$. flavus down to zero level by increasing their concentrations up to $6 \%$ compared with positive control. Several previous reports elucidate the antimicrobial activity of essential oils including lemongrass, citronella, clove, peppermint, thyme and oregano oils against different funga species (Viuda-Martos et al., 2007 and Leyva salas et al., 2017). Also, some of the natural products, such as cinnamon and clove oil (Sukatta et al., 2008), phenols (Pizzolitto et al., 2015), some spices (Hasan and Mahmoud, 1993 and Ibrahim et al., 2017) and many essential oils (Soliman and Badeaa, 2002 and Youssef et al., 2016) have been reported as effective inhibitors of fungal growth and aflatoxin production.

Considering the massive variety of various groups of chemical compounds present in essential oils, it's possibly that their antimicrobial activity isn't due to one specific mechanism however to the existence of many targets within the cell (Carson et al., 2002). According to Pawar and Thaker (2006), the physical nature of essential oils, i.e. low mass combined with pronounced lipophilic tendencies enable them to penetrate cell wall additional quickly than alternative substances. Conner and Beuchat (1984 a, b) and Chouhan et al. (2017) suggested that the antimicrobial activity of essential oils or their constituents like thymol, carvacrol, vanillin may well be the results of injury to the catalyst cell system, as well as those related to energy production and synthesis of structural compounds.

Nychas (1995) and Pillai and Ramaswamy (2012) indicated that phenolics might denature the enzymes to blame for spore germination or interfere with the amino acid concerned in germination. Rasooli and Owlia (2005); Helal et al (2007) and Sharifi-Rad et al. (2017) showed irreversible injury in cel membrane, cytomembrane and cellular organelles once A. parasiticus and $A$ flavus were exposed to totally different essential oils

It was found that organic acids such as salicylic acid have antimicrobial effects (Kupferwasser et al., 2003). It seems that salicylic acid prevented aflatoxin production due to reduced fungal growth and could delay $\mathrm{AFB}_{1}$ aggregation for a few days. In this regards, Hassan et al. (2015) studied the result of eight organic acids (propionic, acetic, formic, lactic, tartaric, citric, oxalic and malic acids) as antifungal agents on the expansion and toxins production of 4 fungi (Aspergillus flavus, Penicillium purpurogenum, Rhizopus nigricans and Fusarium oxysporum).They found that the highest inhibition (50\%) of $\mathrm{AFB}_{1}$ production was observed by $R$. nigricans in the presence of formic acid (10\%). Panahirad $\boldsymbol{e}$ al (2014) stated that salicylic acid has been shown to inhibit the mycelial growth and mycotoxin production of A. flavus and could be an alternative to fungicidal agents. Bullerman (1983), Shi-Jenq (1986), Mahjoub and Bullerman (1986) and Al-Ashmawy and Ibrahim (2009) reported that Aflatoxin production was reduced and inhibited mold growth by potassium sorbate and calcium propionate. Beeswax and propolis had a highly effect on the aflatoxins production that agreement with few investigations demonstrated an antimicrobial viability of beeswax against overall Staphylococcus aureus, Salmonella enterica, Candida albicans and Aspergillus niger (Fratini et al., 2016). Propolis had antimicrobial, antiviral, antifungal and anti-inflammatory properties, its use in drugs dates back to earlier period (Wulandari et al., 2013 and Freires $\boldsymbol{e t}$ al., 2016). Extending fruits shelf life and preventing fungal decay during storage as a result of using propolis were reported (Candir et $\boldsymbol{a l} ., 2009$ and Özdemir et al., 2010). The propolis contains about $50 \%$ resins, $30 \%$ wax, $10 \%$ essential oils, $5 \%$ pollen and $5 \%$ other organic compounds (Falcão et al., 2010). Many investigation demonstrated the highly antimicrobial effect of propolis at different concentration of its extracts as Bankova (2005b), Soylu et al., (2004, 2008), Candir et al., (2009), Curifuta et al., (2012), Matny et al., (2014, 2015) and Hegazi et al. (2014). The presence of phenolic compounds, waxes, vitamins and essential oils could have the most significant biological action of propolis in inhibiting the microbial activity (Burdock, 1998).

In this concern, there are some papers about the application of beeswax based edible films and coatings in the preservation of fruits and vegetables (NavarroTarazaga and Pérez-Gago, 2006; Galič, 2009 and Abdel-Kader et al., 2019). However, according to our knowledge, there are no many papers about the incorporation of natural biologically active compounds in the beeswax coating. The beeswax could be an advanced mixture (more than three hundred components) of hydrocarbons, free fatty acids, esters of fatty acids and fatty alcohol, di-esters and exogenous substances (Tulloch, 1980). Crude beeswax showed antifungal (Al-
Waili, 2004) and antibacterial activity against Gram-positive and Gram-negative bacteria (Nevine, 2011). Also, Fagundes et al. (2015) recorded that edible composite coating of sodium benzoate based on either hydroxypropyl methylcellulose or beeswax was the most effective than sodium methyl paraben and sodium ethyl paraben against Alternaria alternata black spot on artificially inoculated cherry tomatoes.

\section{CONCLUSION}

Our results indicate that food preservative from natural sources as carnation oil, lemongrass oil, beeswax and propolis were more effective against aflatoxigenic fungi and its toxins production during storage than chemical preservative as salicylic acid and potassium sorbate, at the concentrations $(0.25$ to $6 \%)$. It is suggested that natural substances could be used to prevent growth of aflatoxigenic fungi and its toxins production in stored maize grains.

Acknowlegment: This research was financially supported in part by In-House project No. 11030132 of National Research Centre; Egypt entitled "Integrated Management of Diseases Affecting Maize Crop during Vegetative Growth and Storage Periods".

\section{REFERENCES}

Abarca, M. L., Bragulat, M. R., Castella, G., \& Cabanes, F. J. (1994). Mycoflora and aflatoxin-producing strains in animal mixed feeds. Journal of Food Protection, 57(3), 256-258.https://doi.org/10.4315/0362-028X-57.3.256

Abdel-Kader, M.M., EL-Mougy, N.S. \& Khalil, M.S.A. (2019). First record of black spot disease infecting Guava fruits in Egypt and its pre and post-harvest management. BioScience Research. 16(2), 2104-2118.

Abdel-Rahman, G. N., Sultan, Y. Y., Salem, S. H., \& Amer, M. M. (2019). Identify the natural levels of mycotoxins in Egyptian roasted peanuts and the destructive effect of gamma radiation. Journal of Microbiology, Biotechnology and Food Sciences, 1174-1177. https://doi.org/10.15414/jmbfs.2019.8.5.1174 $\underline{1177}$

Abdollahi, A., \& Buchanan, R. L. (1981). Regulation of aflatoxin biosynthesis: induction of aflatoxin production by various carbohydrates. Journal of Food Science, 46(2), 633-635.https://doi.org/10.1111/j.1365-2621.1981.tb04928.x

Al-Ashmawy, M. A., \& Ibrahim, J. I. (2009). Influence of potassium sorbate on the growth of yeasts and moulds in yogurt. International journal of dairy technology, 62(2), 224-227.https://doi.org/10.1111/j.1471-0307.2009.00463.x

Al-Waili, N. S. (2004). An alternative treatment for pityriasis versicolor, tinea cruris, tinea corporis and tinea faciei with topical application of honey, olive oil and beeswax mixture: an open pilot study. Complementary therapies in medicine, 12(1), 45-47. https://doi.org/10.1016/j.ctim.2004.01.002

Aly, S. A., \& Elewa, N. A. (2007). The effect of Egyptian honeybee propolis on the growth of Aspergillus versicolor and sterigmatocystin biosynthesis in Ras $\begin{array}{llll}\text { cheese. Journal of dairy research, } & 74(1), \quad 74\end{array}$ 78.https://doi.org/10.1017/S002202990600207X

AOAC. (2016). Official Methods of Analysis Association of Official Analytical Chemistry. $13^{\text {th }}$ Ed., USA, $971 \mathrm{p}$.

Awadall, O. A., Abuel-Souod, S. M., Assawah, S. M., \& El-Debaky, S. A. (2008). Control of dry and soft rot disease of potato tubers using essential oils, fungicides and antagonistic fungi. The Egyptian Society of Experimental Biology, 4, 1-11.

Badawy, I. F. (2016). Effect of Ethanol-Extracted Propolis on Fruit Quality and Storability of Balady Oranges During Cold Storage. Assiut Journal of Agricultural Science, 47(4), 156-166.

Bankova, V. (2005a). Recent trends and important developments in propolis research. Evidence-based complementary and alternative medicine, 2(1), 2932.http://dx.doi.org/10.1093/ecam/neh059

Bankova, V. (2005b). Chemical diversity of propolis and the problem of standardization. Journal of ethnopharmacology, 100(1-2), 114 117.https://doi.org/10.1016/j.j.jep.2005.05.004

Banskota, A. H., Tezuka, Y., Adnyana, I. K., Ishii, E., Midorikawa, K., Matsushige, K., \& Kadota, S. (2001). Hepatoprotective and anti-Helicobacter pylori activities of constituents from Brazilian propolis. Phytomedicine, 8(1), 16 23.https://doi.org/10.1078/0944-7113-00004

Buchta, V., Černý, J., \& Opletalová, V. (2011). In vitro antifungal activity of propolis samples of Czech and Slovak origin. Open Life Sciences, 6(2), 160 166.https://doi.org/10.2478/s11535-010-0112-3

Bullerman, L. B. (1983). Effects of potassium sorbate on growth and aflatoxin production by Aspergillus parasiticus and Aspergillus flavus. Journal of food protection, 46(11), 940-942.https://doi.org/10.4315/0362-028X-46.11.940

Burdock, G. A. (1998). Review of the biological properties and toxicity of bee propolis (propolis). Food and Chemical toxicology, 36(4), 347363.https://doi.org/10.1016/S0278-6915(97)00145-2

Candir, E. E., Ozdemir, A. E., Soylu, E. M., Sahinler, N., \& Gul, A. (2009) Effects of propolis on storage of sweet cherry cultivar Aksehir Napolyon. Asian J. Chem, 21, 2659-2666. 
Carson, C. F., Mee, B. J., \& Riley, T. V. (2002). Mechanism of action of Melaleuca alternifolia (tea tree) oil on Staphylococcus aureus determined by time-kill, lysis, leakage, and salt tolerance assays and electron microscopy. Antimicrobial agents and chemotherapy, 46(6), 19141920.https://doi.org/10.1128/AAC.46.6.1914-1920.2002

Chouhan, S., Sharma, K., \& Guleria, S. (2017). Antimicrobial activity of some essential oils-present status and future perspectives. Medicines, 4(3), 58.https://doi.org/10.3390/medicines4030058

Conner, D. E., \& Beuchat, L. R. (1984a). Effects of essential oils from plants on growth of food spoilage yeasts. Journal of food science, 49(2), 429434.https://doi.org/10.1111/j.1365-2621.1984.tb12437.x

Conner, D. E., \& Beuchat, L. R. (1984b). Sensitivity of heat-stressed yeasts to essential oils of plants. Appl. Environ. Microbiol., 47(2), 229-233.

Curifuta, M., Vidal, J., Sánchez-Venegas, J., Contreras, A., Salazar, L. A., \& Alvear, M. (2012). The in vitro antifungal evaluation of a commercial extract of Chilean propolis against six fungi of agricultural importance. Ciencia $e$ investigación agraria, 39(2), 347-359.

Davis, N. D., Iyer, S. K., \& Diener, U. L. (1987). Improved method of screening for aflatoxin with a coconut agar medium. Appl. Environ. Microbiol., 53(7), 1593-1595.

El-Nagerabi, S. A., Al-Bahry, S. N., Elshafie, A. E., \& Alhilali, S. (2012). Effect of Hibiscus sabdariffa extract and Nigella sativa oil on the growth and aflatoxin B1 production of Aspergillus flavus and Aspergillus parasiticus strains. Food Control, 25(1), 59-63. https://doi.org/10.1016/j.foodcont.2011.09.033

Elshafie, S. Z., Elmubarak, A., El-Nagerabi, S. A., \& Elshafie, A. E. (2011). Aflatoxin B 1 contamination of traditionally processed peanuts butter for human consumption in Sudan. Mycopathologia, 171(6), 435-439.

Fagundes, C., Palou, L., Monteiro, A. R., \& Pérez-Gago, M. B. (2015) Hydroxypropyl methylcellulose-beeswax edible coatings formulated with antifungal food additives to reduce alternaria black spot and maintain postharvest quality of cold-stored cherry tomatoes. Scientia Horticulturae, 193, 249257.https://doi.org/10.1016/j.scienta.2015.07.027

Falcão, S. I., Vilas-Boas, M., Estevinho, L. M., Barros, C., Domingues, M. R., \& Cardoso, S. M. (2010). Phenolic characterization of Northeast Portuguese propolis: usual and unusual compounds. Analytical and bioanalytical chemistry, 396(2), 887-897.

FAO. (2013). Food Agriculture Orgnization Statistical Yearbook 2013 - World Food and Agriculture.

Fente, C. A., Ordaz, J. J., Vazquez, B. I., Franco, C. M., \& Cepeda, A. (2001) New additive for culture media for rapid identification of aflatoxin-producing Aspergillus strains. Appl. Environ. Microbiol., 67(10), 48584862.https://doi.org/ 10.1128/AEM.67.10.4858-4862.2001

Fountain, J., Scully, B., NI, X., Kemerait, R., Lee, D., Chen, Z. Y., \& Guo, B. (2014). Environmental influences on maize-Aspergillus flavus interactions and aflatoxin production. Frontiers in microbiology, 5 , 40.https://doi.org/10.3389/fmicb.2014.00040

Fratini, F., Cilia, G., Turchi, B., \& Felicioli, A. (2016). Beeswax: A minireview of its antimicrobial activity and its application in medicine. Asian Pacific Journal of Tropical $\quad$ Medicine, $\quad 9(9), \quad$ 839843.https://doi.org/10.1016/j.apjtm.2016.07.003

Freires, I. A., Queiroz, V. C. P. P., Furletti, V. F., Ikegaki, M., De Alencar, S. M., Duarte, M. C. T., \& Rosalen, P. L. (2016). Chemical composition and antifungal potential of Brazilian propolis against Candida spp. Journal de mycologie medicale, 26(2), 122-132.https://doi.org/10.1016/j.mycmed.2016.01.003

Galič, K. (2009). Edible films in the food industry. Croatian J Food Technol. Biotechnol. Nutrition, 4 (1-2): 23-31.

Ghasem, Y. B., Ownagh, A., \& Hasanloei, M. (2007). Antibacterial and antifungal activity of Iranian propolis against Staphylococcus aureus and Candida albicans. Pakistan journal of biological sciences: PJBS, 10(8), 13431345.https:// doi.org/ 10.3923/pibs.2007.1343.1345

Hasan, H. A. H., \& Mahmoud, A. L. (1993). Inhibitory effect of spice oils on lipase and mycotoxin production. Zentralblatt für Mikrobiologie, 148(8), 543548.https://doi.org/10.1016/S0232-4393(11)80218-0

Hassan, R., El-Kadi, S., \& Sand, M. (2015). Effect of some organic acids on some fungal growth and their toxins production. Int J Adv Biol, 2(1), 1-11.

Hegazi, A. G., El Hady, F. K. A., \& Allah, F. A. A. (2000). Chemical composition and antimicrobial activity of European propolis. Zeitschrift für Naturforschung C, 55(1-2), 70-75. https://doi.org/10.1515/znc-2000-1-214

Hegazi, A., Abdou, A. M., \& Abd Allah, F. (2014). Egyptian Propolis 11: Its antimicrobial activity with comparison with different localities. Int. J. Curr. Microbiol. App. Sci, 3(9), 530-538.

Helal, G. A., Sarhan, M. M., Abu Shahla, A. N. K., \& Abou El-Khair, E. K (2007). Effects of Cymbopogon citratus L. essential oil on the growth, morphogenesis and aflatoxin production of Aspergillus flavus ML2-strain. $\begin{array}{llll}\text { Journal of } & \text { Basic } & \text { Microbiology, } & \text { 47(1), }\end{array}$ 15.https://doi.org/10.1002/jobm.200610137

Ibrahim, F., Asghar, M. A., Iqbal, J., Ahmed, A., \& Khan, A. B. (2017) Inhibitory effects of natural spices extracts on Aspergillus growth and aflatoxin synthesis. Australian Journal of Crop Science, 11(12), 1553.
Klich, M. A. (2002). Identification of common Aspergillus species. Centraalbureau voor schimmelcultures. https://doi.org/10.1017/S0269915X03243123

Krell, R. (1996). Value-added products from beekeeping (No. 124). Food \& Agriculture Org.

Kumar, A., Shukla, R., Singh, P., \& Dubey, N. K. (2010). Chemical composition, antifungal and antiaflatoxigenic activities of Ocimum sanctum L. essential oil and its safety assessment as plant based antimicrobial. Food and Chemical Toxicology, 48(2), 539-543. https://doi.org/10.1016/j.fct.2009.11.028

Kumari, R., Jayachandran, L. E., \& Ghosh, A. K. (2019). Investigation of diversity and dominance of fungal biota in stored wheat grains from governmental warehouses in West Bengal, India. Journal of the Science of Food and Agriculture, 99 (7), 3490-3500.https://doi.org/10.1002/jsfa.9568

Kupferwasser, L. I., Yeaman, M. R., Nast, C. C., Kupferwasser, D., Xiong, Y. Q., Palma, M. \& Bayer, A. S. (2003). Salicylic acid attenuates virulence in endovascular infections by targeting global regulatory pathways in Staphylococcus aureus. The Journal of clinical investigation, 112(2), 222-233.

Lambert, R. J. W., Skandamis, P. N., Coote, P. J., \& Nychas, G. J. (2001). A study of the minimum inhibitory concentration and mode of action of oregano essential oil, thymol and carvacrol. Journal of applied microbiology, 91(3), 453462. https://doi.org/10.1046/j.1365-2672.2001.01428.x

Leyva Salas, M., Mounier, J., Valence, F., Coton, M., Thierry, A., \& Coton, E. (2017). Antifungal microbial agents for food biopreservation-a review. Microorganisms, 5(3), 37. https://doi.org/10.3390/microorganisms5030037

Mahjoub, A., \& Bullerman, L. B. (1986). Effects of natamycin and potassium sorbate on growth and aflatoxin production in olives. Archives de l'Institut Pasteur de Tunis, 63(4), 513-525.

Marcucci, M. C., Ferreres, F., Garcia-Viguera, C., Bankova, V. S., De Castro, S L., Dantas, A. P. \& Paulino, N. (2001). Phenolic compounds from Brazilian propolis with pharmacological activities. Journal of ethnopharmacology, 74(2), 105-112.https://doi.org/10.1016/S0378-8741(00)00326-3

Matny, O. N., Abdul-Karim, E. K., Naemah, R. A., \& Al-Ani, R. A. (2014) Activity of propolis and Boswellia sp. resins extract against Sclerotinia sclerotiorum causative agent of white rot disease of Phaseolus vulgaris and Daucus carota under storage conditions. J. Exp. Biol. Agric. Sci, 2, 65-71.

Matny, O. N., Al-Warshan, S. H., \& Ali, A. M. (2015). Antifungal evaluation of Iraqi propolis against Penicillium expansum and mycotoxin production in apple. Int. J. Curr. Microbiol. App. Sci, 4(11), 399-405.

Merck, (2015). The merk index online, Combridge,UK, Royal society of chemistry.

Navarro-Tarazaga, M. L., \& Pérez-Gago, M. B. (2006). Effect of edible coatings on quality of mandarins cv. Clemenules. In Proceedings of the Florida State Horticultural Society (Vol. 119, pp. 350-352). Florida State Horticultural Society. Nawar, L. S. (2008). Prevention and control of fungi contaminated stored pistachio nuts imported to Saudi Arabia. Saudi J. Biol. Sci, 15(1), 105-112.

Nevine, G. B. (2011). Study on the antimicrobial activity of honey products and some Saudi Folkloric substances. Research Journal of Biotechnology, 6(4), 3843.

Nychas, G. J. E. (1995). Natural antimicrobials from plants. In New methods of food preservation (pp. 58-89). Springer, Boston, MA

Ominski, K. H., Marquardt, R. R., Sinha, R. N., \& Abramson, D. (1994). Ecological aspects of growth and mycotoxin production by storage fungi. Mycotoxins in grains. Compounds other than aflatoxin. Eagen Press, USA. p, 287-305.

Özdemir, A. E., Candir, E. E., Kaplankiran, M., Soylu, E. M., Sahinler, N., \& Gül, A. (2010). The effects of ethanol-dissolved propolis on the storage of grapefruit cv. Star Ruby. Turkish Journal of Agriculture and Forestry, 34(2), 155-162.https://doi:10.3906/tar-0902-50

Panahirad, S., Zaare-Nahandi, F., Mohammadi, N., Alizadeh-Salteh, S., \& Safaie, N. (2014). Effects of salicylic acid on Aspergillus flavus infection and aflatoxin B1 accumulation in pistachio (Pistacia vera L.) fruit. Journal of the Science of Food and Agriculture, 94(9), 1758-1763.https://doi.org/10.1002/jsfa.6488

Pawar, V. C., \& Thaker, V. S. (2006). In vitro efficacy of 75 essential oils against Aspergillus niger. Mycoses, 49(4), 316-323.https://doi.org/10.1111/j.14390507.2006.01241.x

Pillai, P., \& Ramaswamy, K. (2012). Effect of naturally occurring antimicrobials and chemical preservatives on the growth of Aspergillus parasiticus. Journal of food science and technology, 49(2), 228-233.

Pizzolitto, R. P., Barberis, C. L., Dambolena, J. S., Herrera, J. M., Zunino, M. P., Magnoli, C. E., \& Dalcero, A. M. (2015). Inhibitory effect of natural phenolic compounds on Aspergillus parasiticus growth. Journal of Chemistry.http://dx.doi.org/10.1155/2015/547925

Quiroga, E. N., Sampietro, D. A., Soberón, J. R., Sgariglia, M. A., \& Vattuone, M. A. (2006). Propolis from the northwest of Argentina as a source of antifungal principles. Journal of Applied Microbiology, 101(1), 103110.https://doi.org/10.1111/j.1365-2672.2006.02904.x

Qureshi, H., Hamid, S. S., Ali, S. S., Anwar, J., Siddiqui, A. A., \& Khan, N. A. (2015). Cytotoxic effects of aflatoxin B1 on human brain microvascular endothelial cells of the blood-brain barrier. Medical mycology, 53(4), 409416.https://doi.org/10.1093/mmy/myv010 
Jadhav Rajesh, K., \& Mulla, M. (2018). Screening Of Organic Acids Production By Fungi Grown On Extracts From various Leaves After Protein Isolation In Vitro: The Novel Industrial Approach. International Journal Of Pharmacy And Pharmaceutical Research, 13(4), 266-276.

Rasooli, I., \& Owlia, P. (2005). Chemoprevention by thyme oils of Aspergillus parasiticus growth and aflatoxin production. Phytochemistry, 66(24), 28512856.https://doi.org/10.1016/j.phytochem.2005.09.029

Samson, R. A., Hoekstra, E. S., \& Frisvad, J. C. (2004). Introduction to food-and airborne fungi (No. Ed. 7). Centraalbureau voor Schimmel cultures (CBS).

SAS (1999). Statistical Analysis System, SAS / STAT User's Guide. Release 6.03 Edn. SAS Institute, Cary, NC, 1028 PP.

Sharifi-Rad, J., Sureda, A., Tenore, G. C., Daglia, M., Sharifi-RAD, M., Valussi,

M. \& Sharifi-Rad, R. (2017). Biological activities of essential oils: From plant chemoecology to traditional healing systems. Molecules, 22(1), 70.https://doi.org/10.3390/molecules22010070

Shi-Jenq, L. (1986). Effect of food preservatives on fungal interaction and aflatoxin production. Ph. D. University of Nebraska - Lincoln, ProQuest Dissertations Publishing, 1986. 8614459.

Smith-Palmer, A., Stewart, J., \& Fyfe, L. (2001). The potential application of plant essential oils as natural food preservatives in soft cheese. Food microbiology, 18(4), 463-470.https://doi.org/10.1006/fmic.2001.0415

Soliman, K. M., \& Badeaa, R. I. (2002). Effect of oil extracted from some medicinal plants on different mycotoxigenic fungi. Food and chemical toxicology, 40 (11), 1669-1675.https://doi.org/10.1016/S0278-6915(02)00120-5 Soylu, E. M., Ozdemir, A. E., Erturk, E., \& Sahinler, N. (2004), September Antifungal activity of propolis against Penicillium Digitatum, causal agent of green mold of citrus fruits. In Proceedings of the First European Conference of Apidology 'EurBee', Udine, Italy (Vol. 160).

Soylu, E. M., Özdemir, A. E., Ertürk, E., Şahinler, N., \& Soylu, S. (2008) Chemical composition and antifungal activity of propolis against Penicillium digitatum. Asian Journal of Chemistry, 20, 4823-4830.

Sukatta, U., Haruthaithanasan, V., Chantarapanont, W., Dilokkunanant, U., \& Suppakul, P. (2008). Antifungal activity of clove and cinnamon oil and their synergistic against postharvest decay fungi of grape in vitro. Kasetsart J. Nat. Sci, 42, 169-174.

Tepe, B., Daferera, D., Sokmen, A., Sokmen, M., \& Polissiou, M. (2005) Antimicrobial and antioxidant activities of the essential oil and various extracts of Salvia tomentosa Miller (Lamiaceae). Food chemistry, 90(3), 333 340.https://doi.org/10.1016/j.foodchem.2003.09.013

Tulloch, A. P. (1980). Beeswax - composition and analysis. Bee World, 61(2), 47-62.

Viuda-Martos, M., Ruiz-Navajas, Y., Fernández-López, J., \& Pérez-Álvarez, J A. (2007). Antifungal activities of thyme, clove and oregano essential oils. Journal of food safety, 27(1), 91-101. https://doi.org/10.1111/j.17454565.2007.00063.x

Wulandari, R., Amin, S., \& Silviana, A. (2013). Tinea faciei caused by Trichophyton rubrum melanoid type and pityriasis versicolor. Indian J Dermatol Venereol Leprol, 2, 59-65.

Yang, S., Peng, L., Cheng, Y., Chen, F., \& Pan, S. (2010). Control of citrus green and blue molds by Chinese propolis. Food Science and Biotechnology, 19 (5), 1303-1308.https://doi.org/10.1007/s10068-010-0186-8

Youssef, M. M., Pham, Q., Achar, P. N., \& Sreenivasa, M. Y. (2016). Antifungal activity of essential oils on Aspergillus parasiticus isolated from peanuts. Journal of plant protection research, 56(2), 139-142.https://doi.org./ 10.1515/.jppr2016-0021 